Gelanggang Pendidikan Jasmani Indonesia

\title{
PENGEMBANGAN MEDIA PEMBELAJARAN JURUS TUNGGAL PENCAK SILAT BERBASIS ANDROID
}

\author{
Rian Triprayogo ${ }^{1}$, Panggung Sutapa ${ }^{2}$, Rifqi Festiawan ${ }^{3}$, Sendy Mohamad Anugrah ${ }^{4}$, \\ Dody Tri Irwandana ${ }^{5 \bowtie}$
}

Universitas Sultan Ageng Tirtayasa ${ }^{1 \& 4}$, Universitas Negeri Yogyakarta ${ }^{2}$, Universitas Jenderal Soedirman $^{3}$, Universitas Mercu Buana Yogyakarta ${ }^{5}$

\begin{tabular}{l} 
riantriprayogo@untirta.ac.id \\
\hline Info Artikel \\
\hline Sejarah Artikel: \\
Diterima: September, 2020 \\
Disetujui: Oktober, 2020 \\
Dipublikasikan : Desember, 2020 \\
\hline Kata Kunci: \\
Media Pembelajaran, Jurus \\
Tunggal, Android, Pencak Silat.
\end{tabular}
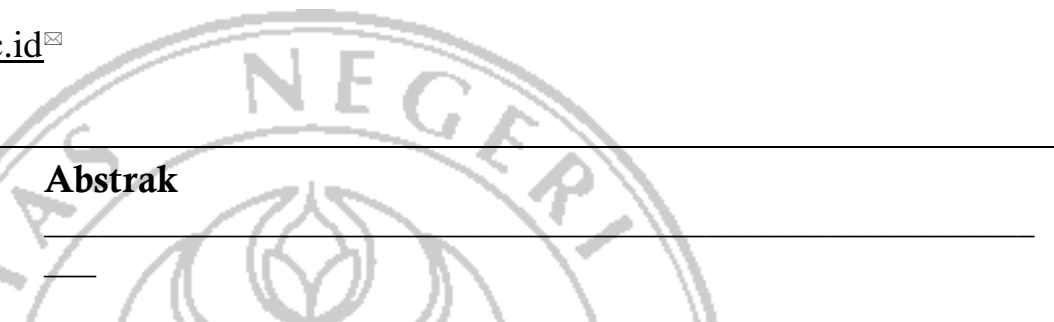

Tujuan penelitian ini adalah mengembangkan media pembelajaran jurus tunggal pencak silat berbasis android. Penelitian ini dilaksanakan di SMP Budi Mulia Dua Sleman, SMP Mataram Bantul, MTs Ali Maksum Bantul, dan SMP Muhammadiyah 4 Yogyakarta. Uji lapangan awal dilaksanakan di SMP Budi Mulia Dua Sleman menggunakan 12 siswa ekstrakurikuler pencak silat dan 1 guru. Uji lapangan utama dilakukan di SMP Mataram Bantul dan MTs Ali Maksum menggunakan 32 siswa ekstrakurikuler pencak silat dan 2 guru. Uji lapangan operasional dilakukan di SMP Muhammadiyah 4 Yogyakarta dengan 20 siswa ekstrakurikuler pencak silat. Teknik analisis data dalam penelitian ini yaitu menggunakan analisis deskriptif kuantitatif dan deskriptif kualitatif. Berdasarkan hasil pretest dan posttest yang sudah didapatkan kemudian dilakukan uji efektivitas dengan menggunakan Paired Sample $\mathrm{T}$ Test menggunakan program SPSS. 16 For Windows. Hasil pengembangan media pembelajaran jurus tunggal pencak silat berbasis android efektif untuk meningkatkan hasil belajar pencak silat. Baik dari pengetahuan teori dan praktik gerak jurus tunggal. Hasil penilaian ahli disimpulkan termasuk kategori sangat baik. Hasil uji lapangan operasional menunjukkan signifikansi $<0.5$. Berdasar hasil tersebut maka dapat disimpulkan bahwa media pembelajaran jurus tunggal pencak silat berbasis android efektif untuk meningkatkan hasil belajar jurus tunggal pencak silat. Sehingga media pembelajaran ini layak dan efektif digunakan untuk media pembelajaran jurus tunggal pencak silat.

\begin{abstract}
The purpose of this research is to develop learning media for the single form of martial arts based on android. This research was conducted at SMP Budi Mulia Dua Sleman, SMP Mataram Bantul, MTs Ali Maksum Bantul, and SMP Muhammadiyah 4 Yogyakarta. The initial field test was carried out at SMP Budi Mulia Dua Sleman using 12 pencak silat extracurricular students and 1 teacher. The main field test was conducted at SMP Mataram Bantul and MTs Ali Maksum using 32 pencak silat extracurricular students and 2 teachers. The operational field test was conducted at SMP Muhammadiyah 4 Yogyakarta with 20 pencak silat extracurricular students.
\end{abstract}


The data analysis technique in this research is using quantitative descriptive analysis and qualitative descriptive analysis. Based on the results of the pretest and posttest that have been obtained, then the effectiveness test was carried out using the Paired Sample $T$ Test using the SPSS program. 16 For Windows. The results of the development of learning media for the single form of pencak silat based on Android are effective for improving learning outcomes of pencak silat. Both from the theoretical knowledge and practice of single movement movements. The result of the expert's assessment concluded that it was in the very good category. The operational field test results showed a significance $<0.5$. Based on these results, it can be concluded that the learning media for the single form of pencak silat based on android is effective in improving the learning outcomes of the single form of pencak silat. So that this learning media is feasible and effective to use for learning media for the single style of pencak silat.

(C) 2020 Universitas Negeri Malang

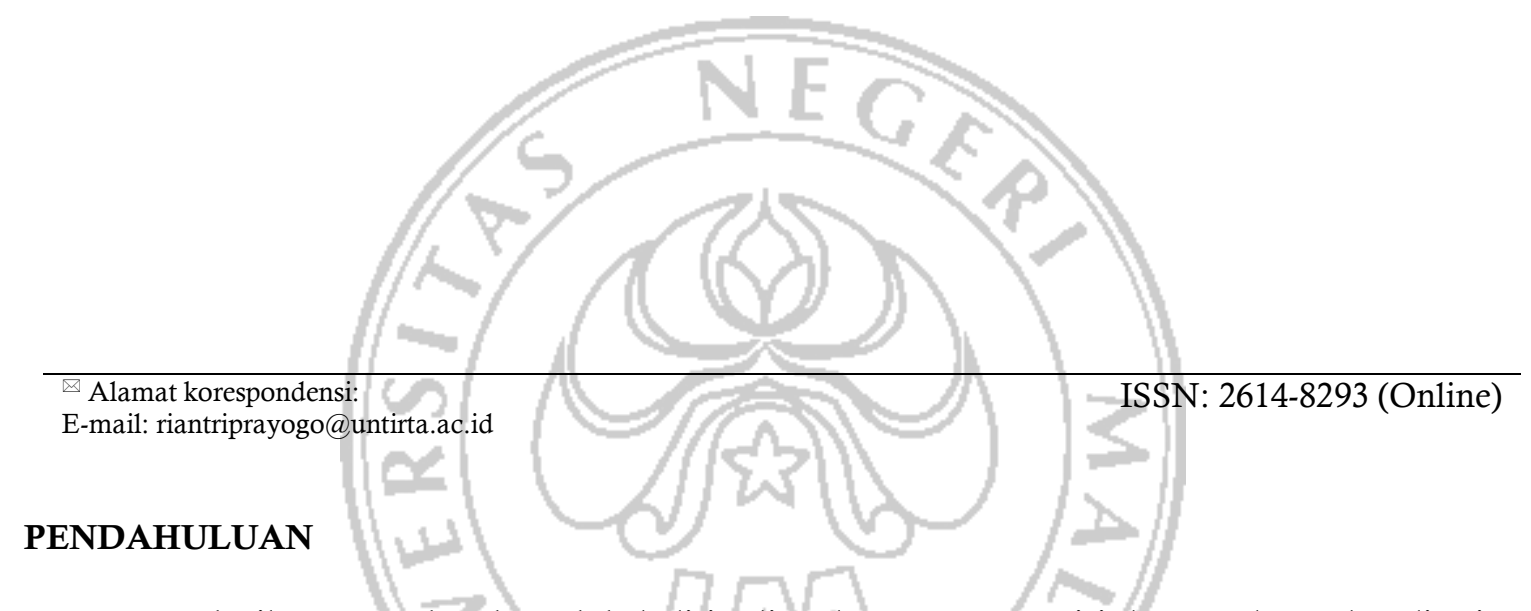

Pencak silat merupakan bentuk beladiri asli melayu yang mengisi daratan dan pulau di asia tenggara (Kumaidah, 2012). Pencak silat merupakan beladiri Indonesia yang digunakan untuk melawan penjajah pada zaman dahulu (Ediyono \& Widodo, 2019). Pencak silat saat ini telah dipertandingkan di single event dan multi event nasional maupun internasional (Dimyati et al., 2020). Pencak silat memiliki 4 kategori yang dipertandingkan yaitu kategori tanding, seni tunggal, ganda, dan regu (Setiawan, 2012). Pencak silat kategori seni tunggal merupakan yang paling sering diperlombakan, dibandingkan dengan kategori seni ganda dan regu (Marwan, 2018). Pembentukan gerakan yang tepat dan sesuai akan menentukan hasil keterampilan kemampuannya (Lestari \& Sutapa, 2020).

Menurut (Cavenett, 2013) media yaitu sebagai segala sesuatu yang dapat digunakan untuk menyalurkan pesan dari pengirim ke penerima sehingga dapat merangsang pikiran, perasaan, perhatian, dan minat serta perhatian siswa. Media digunakan dalam rangka lebih mengefektifkan komunikasi dan interaksi antara guru dengan siswa (Yaumi, 2018). Media juga dapat digunakan untuk menyampaikan informasi, selain itu juga dapat digunakan sebagai penguatan maupun motivasi untuk peserta didik dalam mengikuti proses belajar (Dewi K, 2017).

Pencak silat memerlukan media pembelajaran yang sesuai yang dapat dijadikan media atau sumber belajar (Waskita et al., 2018). Era globalisasi seperti saat ini, setiap orang dapat menggunakan ponsel pintar atau smartphone yang banyak digunakan saat ini yaitu android untuk mempelajari banyak hal (Ajid et al., 2019). Namun, saat ini masih belum terdapat aplikasi untuk mobile internet atau smartphone yang dapat digunakan sebagai sumber belajar jurus tunggal pencak silat (Rahmanto \& Utama, 2018). Peneliti berkeinginan mengembangkan media pembelajaran materi jurus tunggal pencak silat yaitu dengan multimedia berbasis komputer yang di dalamnya berisi video materi jurus tunggal dan teks yang menerangkan setiap gerak dalam jurus tunggal pencak silat. 
Berdasarkan hasil observasi pada seleksi Pekan Olahraga Pelajar Daerah tingkat Kabupaten/ Kota di Provinsi Daerah Istimewa Yogyakarta diperoleh hasil bahwa perolehan nilai skor yang didapat masih rendah. Nilai yang diperoleh kebanyakan pesilat dari setiap juri masih dibawah nilai 90 dari skor maksimal 160. Penyebab kurangnya kompetensi guru dalam jurus tunggal pencak silat ini disebabkan oleh beberapa faktor, seperti guru ekstrakurikuler pencak silat yang tidak memahami jurus tunggal karena tidak pernah mempelajari jurus tunggal. Guru memiliki persepsi gerak yang berbeda dalam jurus tunggal ini sehingga mengajarkan kepada siswa atau pesilatnya hanya sesuai dengan persepsinya saja, akibatnya pesilat tidak menampilkan gerakan jurus yang sudah baku sehingga akan mengurangi nilai kebenarannya. Permasalahan lain yang dialami oleh guru ekstrakurikuler pencak silat adalah alokasi waktu saat jam ekstrakurikuler pencak silat yang hanya 2 jam per minggu. Perlu adanya penelitian untuk mengembangkan multimedia yang mengkombinasikan berbagai kategori media untuk belajar jurus tunggal pencak silat. Multimedia akan terus berkembang seiring dengan perkembangan teknologi informasi dan komunikasi (Aljabar, 2016). Berdasarkan permasalahan tersebut maka peneliti tertarik untuk melakukan penelitian pengembangan dengan judul "Pengembangan Media Pembelajaran Jurus Tunggal Pencak Silat Berbasis Android".

\section{METODE}

Penelitian ini dilaksanakan di smp budi mulia dua sleman, smp mataram bantul, mts ali maksum bantul, dan smp muhammadiyah 4 yogyakarta. Uji lapangan awal dilaksanakan di smp budi mulia dua sleman menggunakan 12 siswa ekstrakurikuler pencak silat dan 1 guru. Uji lapangan utama dilakukan di smp mataram bantul dan mts ali maksum menggunakan 32 siswa ekstrakurikuler pencak silat dan 2 guru. Uji lapangan operasional dilakukan di smp muhammadiyah 4 yogyakarta dengan 20 siswa ekstrakurikuler pencak silat.

Teknik analisis data dalam penelitian ini yaitu menggunakan analisis deskriptif kuantitatif dan deskriptif kualitatif. Analisis data kuantitatif untuk menganalisis data skala nilai validasi, uji lapangan awal, uji lapangan utama dan uji lapangan operasional. Analisis data kualitatif digunakan untuk menganalisis data observasi dan masukan atau saran yang diberikan saat validasi, uji lapangan awal, uji lapangan utama, dan desiminasi. Berdasarkan hasil pretest dan posttest yang sudah didapatkan kemudian dilakukan uji efektivitas dengan menggunakan Paired Sample T Test menggunakan program SPSS. 16 For Windows.

\section{HASIL}

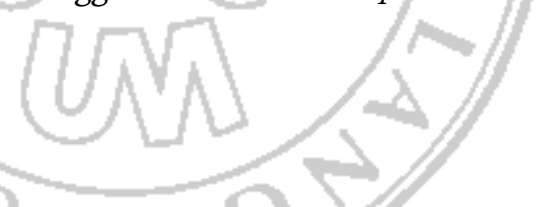

\section{A. Hasil Pengembangan Produk Awal}

Setelah peneliti melakukan kajian literature, observasi, serta studi pendahuluan telah dihasilkan sebuah pengembangan untuk media pembelajaran yaitu jurus tunggal pencak silat. Hasil awal dari pengembangan ini yaitu media belajar jurus tunggal pencak silat berbasis aplikasi komputer disertai dengan buku petunjuknya yang berisi materi gerak jurus tunggal dengan panduan video rincian gerak jurus tunggal pencak silat. Desain awal produk ini adalah media belajar berbasis aplikasi komputer. Pada aplikasi tersebut terdapat panduan belajar jurus tunggal pencak silat dengan video, teks dan suara. Jurus tunggal yang terdiri dari gerak persembahan dan 14 jurus, masing-masing jurus memiliki rangkaian gerak dari 5 hingga 12 gerakan, dan terdapat juga gerak gerak interval.

Aplikasi panduan belajar jurus tunggal pencak silat dalam aplikasi ini dibuat dengan menggolongkan tiap jurus dan lebih diperinci lagi dengan video setiap geraknya dalam masing-masing jurus. Video gerak jurus tunggal ini memperlihatkan peragaan rangkaian gerak pada video jurus dan langkah tiap gerakan dengan video kecepatan normal dan diperlambat. Selain itu juga didalamnya terdapat keterangan langkah untuk melakukan gerakan jurus tunggal sehingga mudah dipahami.

Setelah dikonsultasikan dengan validator, produk ini mendapat masukan untuk: a) Menambahkan materi pencak silat, b) Menambahkan materi teori jurus tunggal, c) Menambahkan contoh blangko pertandingan, d) Menambahkan peraturan pertandingan jurus tunggal, e) Buku petunjuk dibuat berisi materi yang sama dengan media aplikasi, f) Merubah aplikasi berbasis android menjadi aplikasi berbasis ponsel pintar atau android, g) Menambahkan gambar teknik dasar pencak silat. Penilaian oleh validator materi yaitu $84 \%$ dengan kategori sangat baik pada aplikasi dan $84 \%$ 
dengan kategori sangat baik pada buku. Penilaian validator media pada aplikasi $83.33 \%$ dengan kategori sangat baik dan $81.67 \%$ pada buku dengan kategori sangat baik.

B. Hasil Uji Lapangan Awal

Uji lapangan awal dilakukan di SMP Budi Mulia Dua Sleman. Data diperoleh dari hasil kuesioner yang diberikan kepada 12 siswa ekstrakurikuler pencak silat yaitu:

Tabel 1. Hasil Uji Pre-eliminari

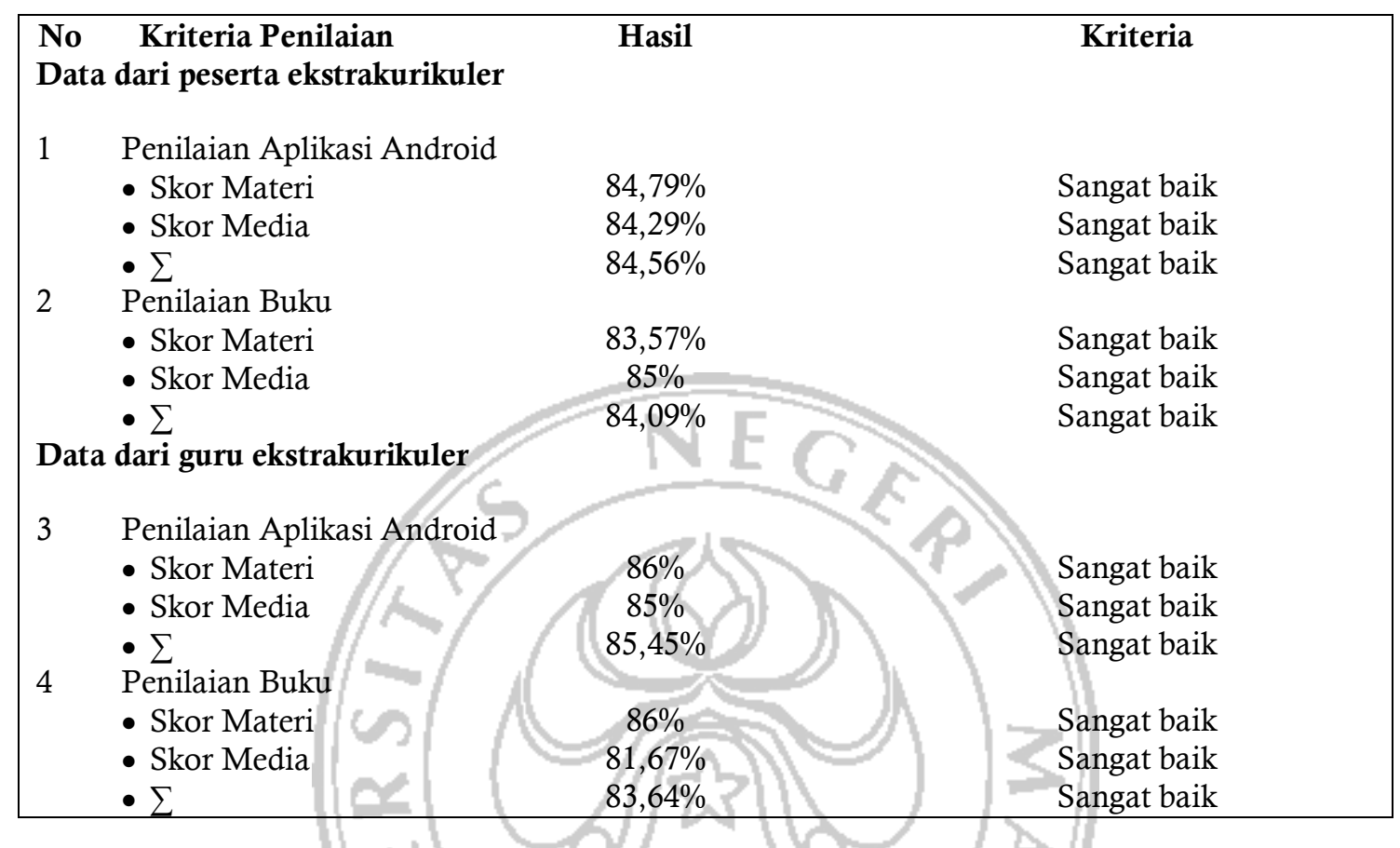

Berdasarkan hasil uji lapangan mendapat nilai dalam kategori sangat baik. Saran diberikan untuk menambahkan ilustrasi gambar guntingan dan tangkapan. Langkah selanjutnya setelah draf produk media pembelajaran jurus tunggal pencak silat mendapatkan validasi dari ahli materi dan mendapatkan validasi dari ahli media maka peneliti melakukan uji lapangan terbatas yang dilakukan pada guru ekstrakurikuler pencak silat dan siswa peserta ekstrakurikuler pencak silat sekolah menengah pertama. Lokasi uji lapangan terbatas di SMP Budi Mulia Dua Sleman.

Uji lapangan terbatas ini dilakukan dengan cara peneliti membagikan media buku dan aplikasi berbasis android. Untuk memperoleh data dalam tahap ini dilakukan dengan cara peneliti membagikan kuesioner. Berdasarkan hasil yang diperoleh dari uji coba lapangan terbatas dapat disimpulkan bahwa pengembangan media pembelajaran jurus tunggal untuk ekstrakurikuler pencak silat ini menurut guru atau pelatih sangat baik pada media buku dan media berbasis android atau ponsel pintar. Hasil yang diperoleh dari siswa juga mendapatkan predikat sangat baik pada media berbasis buku dan media berbasis android. Terdapat saran untuk menambahkan ilustrasi gambar pada guntingan dan tangkapan. Setelah peneliti melakukan revisi untuk menambahkan ilustrasi gambar sesuai dengan masukan maka dapat dilanjutkan pada uji coba lapangan utama.

C. Hasil Uji Lapangan Utama

Uji lapangan utama dilakukan di SMP Mataram Bantul dan MTs Ali Maksum Bantul. Data diperoleh dari hasil kuesioner yang diberikan kepada 32 siswa ekstrakurikuler pencak silat yaitu:

Tabel 2. Hasil Uji Utama

\begin{tabular}{|lll|}
\hline $\begin{array}{l}\text { No } \begin{array}{c}\text { Kriteria Penilaian } \\
\text { Data dari peserta ekstrakurikuler }\end{array} \\
1\end{array} \quad$ Hasil & Kriteria \\
$\begin{array}{l}\text { Penilaian Aplikasi Android } \\
\text { - Skor Materi }\end{array}$ & $88,91 \%$ & Sangat baik \\
\hline
\end{tabular}




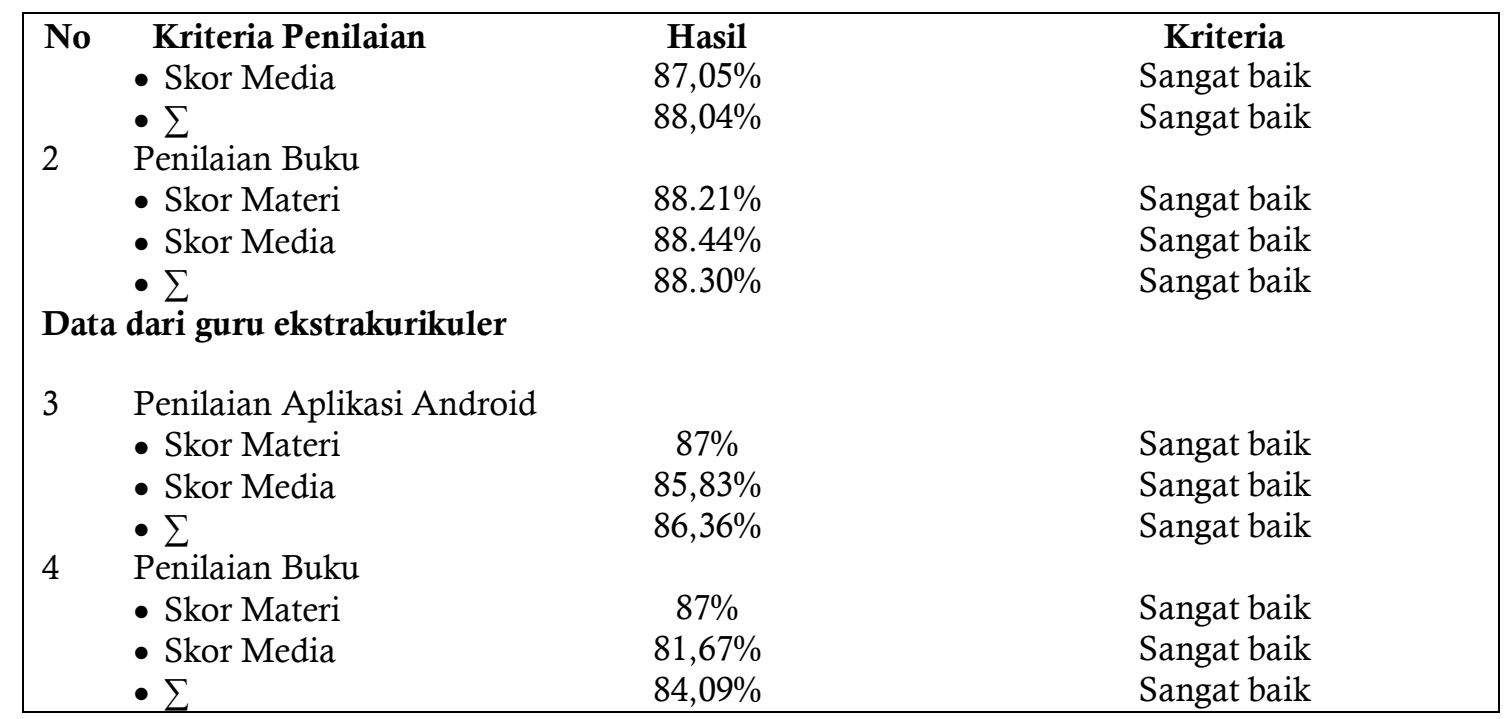

Adapun saran dari guru ekstrakurikuler yaitu untuk menambahkan profil penulis. Berdasarkan hasil yang diperoleh dari data uji lapangan utama dapat disimpulkan bahwa draf pengembangan media pembelajaran jurus tunggal jurus tunggal pencak silat berbasis android mendapat nilai sangat baik. Draf produk ini dapat dilanjutkan ke langkah penelitian selanjutkan yaitu uji lapangan operasional. Draf pengembangan media pembelajaran jurus tunggal pencak silat berbasis android yang telah diuji lapangan terbatas selanjutnya dilakukan proses penelitian selanjutnya yaitu uji lapangan utama. Uji lapangan utama dilakukan pada ekstrakurikuler pencak silat SMP Mataram Bantul dan MTs Ali Maksum Bantul.

Uji lapangan utama media pembelajaran jurus tunggal pencak silat berbasis android dilakukan dengan membagikan draf media pembelajaran jurus tunggal pencak silat kepada guru ekstrakurikuler pencak silat dan siswa peserta ekstrakurikuler pencak silat. Media buku dan aplikasi berbasis android selanjutnya dipelajari oleh siswa ekstrakurikuler pencak silat dengan diberi pengarahan. Untuk memperoleh data penelitian pada uji lapangan utama langkah yang dilakukan oleh peneliti yaitu dengan cara membagikan kuesioner yang akan diisi oleh guru ekstrakurikuler pencak silat dan peserta atau siswa ekstrakurikuler pencak silat.

\section{Hasil Uji Lapangan Operasional}

Uji lapangan operasional dilakukan setelah peneliti melakukan uji lapangan utama dan telah dinyatakan layak untuk dilakukan uji lapangan operasional. Uji lapangan operasional dilakukan di SMP Muhammadiyah 4 Yogyakarta.

Untuk mendapatkan data dari uji lapangan operasional peneliti melakukan tes teori dengan soal pilihan ganda dan tes praktik jurus tunggal kepada 20 siswa peserta ekstrakurikuler pencak silat. Tahap in peneliti memberikan pretest untuk mendapatkan data awal siswa. Setelah dilakukan pretest peneliti memberikan perlakuan selama 3 minggu dengan cara membagikan produk kepada siswa dan memberikan pengarahan cara penggunaan produk. Setelah diberi perlakuan langkah selanjutnya yaitu peneliti mengambil penilaian posttest.

Tabel 3. Paired Samples Statistics Teori.

\begin{tabular}{|lllll|}
\hline & Mean & $\mathbf{N}$ & Std. Deviation & $\begin{array}{l}\text { Std. Error } \\
\text { Mean }\end{array}$ \\
Pair 1 Posttest & 80.0000 & 20 & 4.84496 & 1.08337 \\
Pretest & 70.0500 & 20 & 6.71585 & 1.50171 \\
\hline
\end{tabular}


Tabel 4. Paired Samples Test Teori.

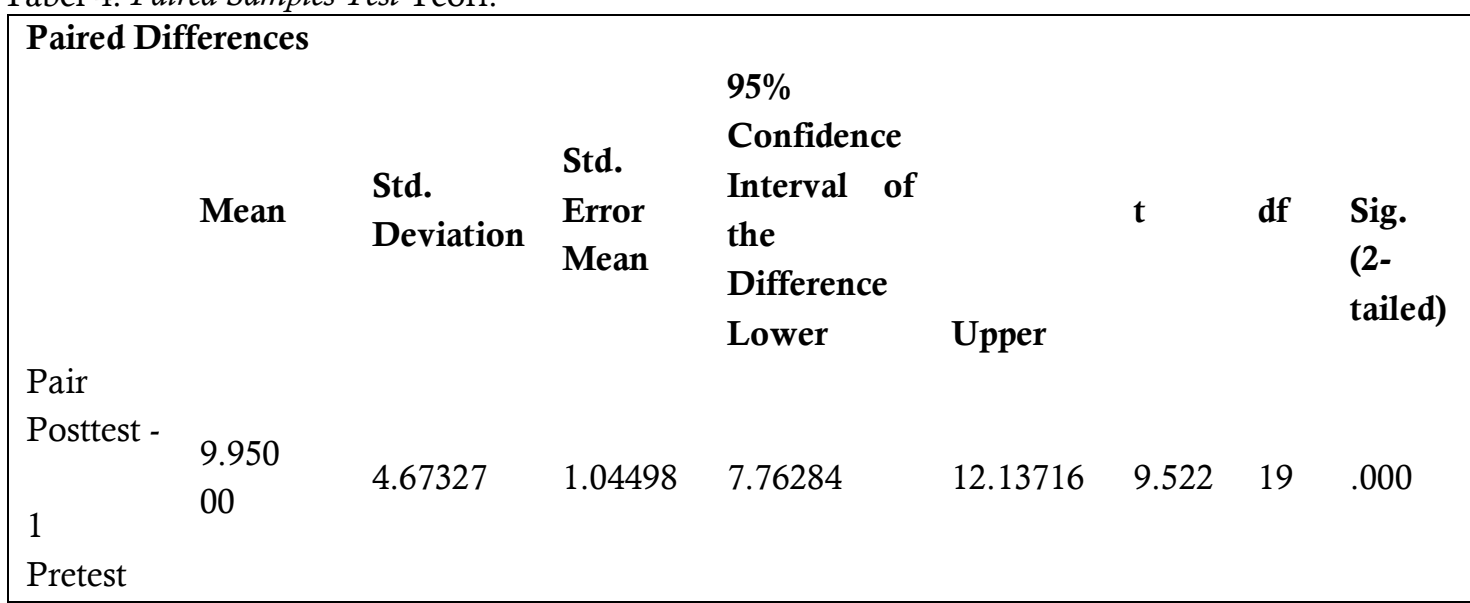

Dari tabel output SPSS di atas, bahwa rata-rata nilai pretest sebesar 70,05 ini dilaksanakan sebelum siswa diberikan perlakuan dengan menggunakan produk pengembangan media pembelajaran jurus tunggal pencak silat dan nilai rata-rata posttest 80,00 . Dilihat dari uji t dimana nilai thitung sebesar 9,52 lebih besar dari ttabel (5\%) sebesar 1,725. Ini juga dapat dilihat dari bagian taraf signifikan (2-tailed), dimana taraf signifikan (2- tailed) sebesar $0,00<0,05$. Hal ini disimpulkan terdapat pengaruh signifikan antara pretest dan posttest pada penggunaan produk pengembangan media pembelajaran jurus tunggal untuk ekstrakurikuler pencak silat.

Tabel 5. Paired Samples Statistics Praktik.

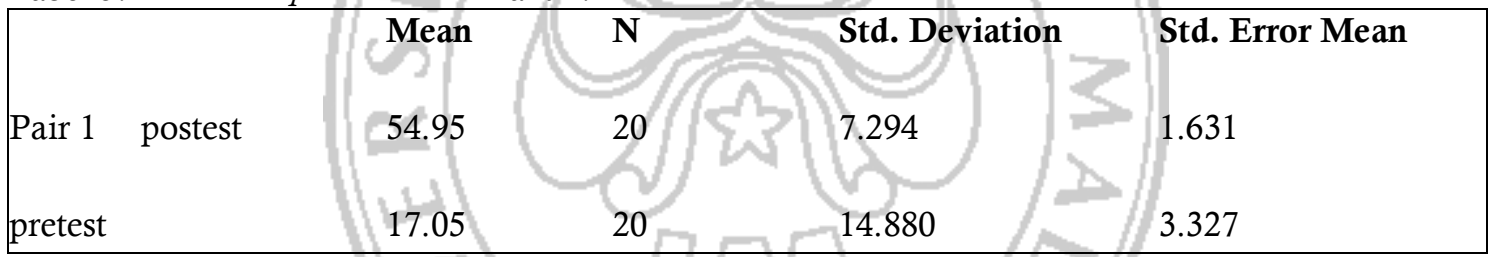

Tabel 6. Paired Samples Test Praktik.

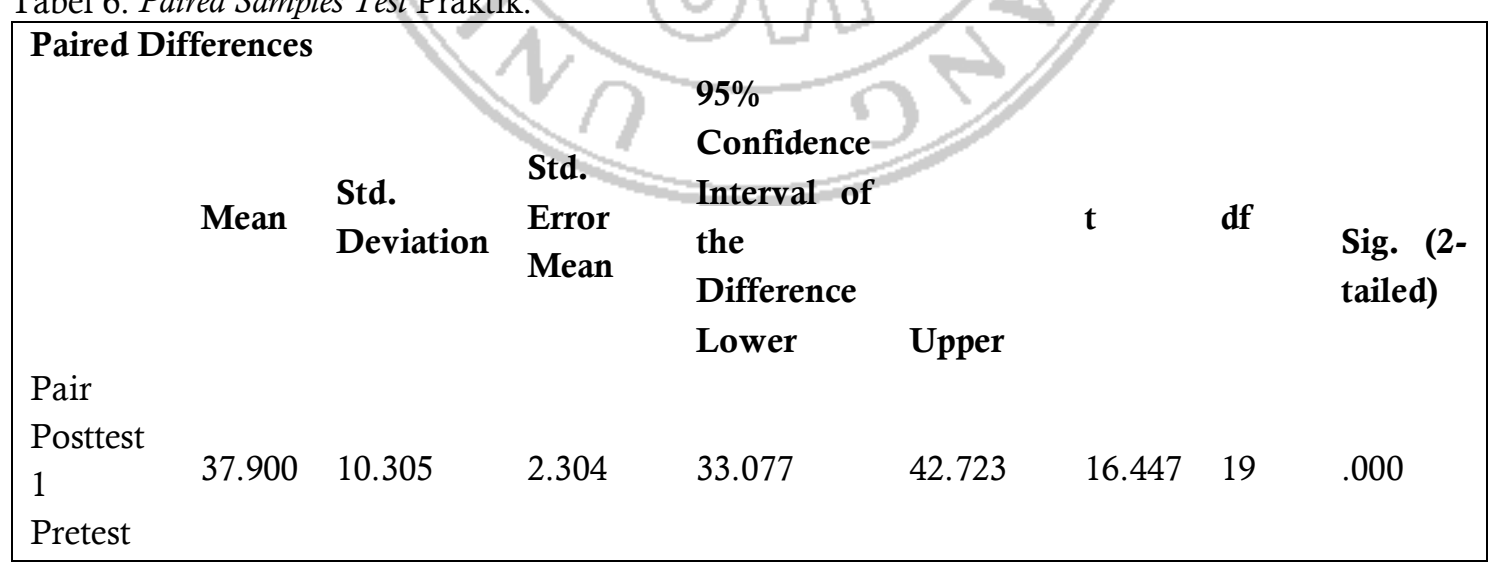

Dari tabel output SPSS di atas, bahwa rata-rata nilai pretest sebesar 17,05 ini dilaksanakan sebelum siswa diberikan perlakuan dengan menggunakan produk pengembangan media pembelajaran jurus tunggal pencak silat dan nilai rata-rata postest 54,95. Dilihat dari uji t dimana nilai thitung sebesar 16,447 lebih besar dari ttabel (5\%) sebesar 1,725. Ini juga dapat dilihat dari bagian taraf signifikan (2-tailed), dimana taraf signifikan (2-tailed) sebesar 0,00<0,05. Hal ini disimpulkan terdapat pengaruh signifikan antara pretest dan posttest pada penggunaan produk pengembangan media pembelajaran jurus tunggal pencak silat. 


\section{PEMBAHASAN}

Media dapat dimanfaatkan dalam proses belajar mengajar karena media menyampaikan pesan lebih mudah dari pemberi pesan kepada penerima pesan (afandi, 2013). Pemanfaatan media yang sistematis dari sumber untuk belajar merupakan proses spesifikasi desain pembelajaran (sebayang et al., 2020). Penelitian yang relevan dengan penelitian ini adalah penelitian yang dilakukan oleh (aljabar, 2016), penelitian tersebut dilatarbelakangi materi pencak silat belum menampilkan gambar proses pelaksanaan, maka diperlukan pengembangan hal tersebut. Penelitian menghasilkan aplikasi sumber belajar materi pencak silat untuk pemula berbasis android. Tetapi pada penelitian sebelumnya tersebut hanya membahas teknik dasar pencak silat. Padahal pencak silat memiliki 4 kategori yang dipertandingkan yaitu kategori tanding, seni tunggal, ganda, dan regu sehingga perlu adanya penelitian pengembangan. Diharapkan dengan adanya penelitian pengembangan ini bisa membantu peserta didik agar bisa berlatih pencak silat khususnya seni jurus tunggal.

\section{KESIMPULAN}

Hasil pengembangan media pembelajaran jurus tunggal pencak silat berbasis android efektif untuk meningkatkan hasil belajar pencak silat. Baik dari pengetahuan teori dan praktik gerak jurus tunggal. Hasil penilaian ahli disimpulkan termasuk kategori sangat baik. Hasil uji lapangan operasional menunjukkan signifikansi $<0.5$. Berdasar hasil tersebut maka dapat disimpulkan bahwa media pembelajaran jurus tunggal pencak silat berbasis android efektif untuk meningkatkan hasil belajar jurus tunggal pencak silat. Sehingga media pembelajaran ini layak dan efektif digunakan untuk media pembelajaran jurus tunggal pencak silat.

\section{DAFTAR PUSTAKA}

Afandi, M. (2013). Model dan Metode Pembelajaran. In Unissula press (p. 202).

Ajid, O. N., Komarudin, K., \& Mulyana, M. (2019). Pengaruh Metode PETTLEP dan Media Audio Visual Terhadap Hasil Belajar Keterampilan Jurus Tunggal Baku Pencak Silat. Jurnal Terapan Ilmu Keolahragaan, 4(2), 107-116. https://doi.org/10.17509/jtikor.v4i2.18989

Aljabar. (2016). Pengembangan Sumber Belajar Materi Pencak Silat Untuk Pemula Berbasis Android. Pendidikan Jasmani Kesehatan Dan Rekreasi, 5(4), 1-7.

Cavenett. (2013). Pengertian Media Pembelajaran Media. Journal of Chemical Information and Modeling, 58(12), 7250-7257.

Dewi K. (2017). Pentingnya Media Pembelajaran. Jurnal Pendidikan Anak Usia Dini, 1(1), 81-96.

Dimyati, Djoko Pekik Irianto, L. R. (2020). Exploring the Psychological Skills of Indonesian Pencak Silat Athletes at the 18th Asian Games. / Badanie umiejętności psychologicznych indonezyjskich zawodników Pencak Silat podczas 18 Igrzysk Azjatyckich. Ido Movement for Culture. Journal of Martial Arts Anthropology, 20(2), 10-16.

Ediyono, S., \& Widodo, S. T. (2019). Memahami Makna Seni dalam Pencak Silat. Panggung, 29(3), 10-14. https://doi.org/10.26742/panggung.v29i3.1014

Kumaidah, E. (2012). Penguatan Eksistensi Bangsa melalui Seni Bela Diri Tradisional Pencak Silat. Humanika: Jurnal Ilmiah Kajian Humaniora, 16(9), 1689-1699.

Lestari, D. S., \& Sutapa, P. (2020). The Skills Development of Pencak Silat Training Model based on Traditional Games Movement. 217-223. https://doi.org/10.5220/0009308702170223

Marwan, I. (2018). Pengembangan Model Pembelajaran Seni Gerak Pencak Silat Berbasis Aplikasi Android. Jurnal Pendidikan Jasmani Dan Olahraga, 3(2), 45-53. 
https://doi.org/10.17509/jpjo.v3i2.12453

Rahmanto, Y., \& Utama, R. Y. (2018). Penerapan Teknologi Web3D Berbasis Android Sebagai Media Pembelajaran Gerakan Dasar Silat. Jurnal TAM (Technology Acceptance Model), 9(1), 714.

Sebayang, F. A. A., Saragih, O., \& Hestina, H. (2020). Pemanfaatan Media Pembelajaran Online untuk Meningkatkan Pembelajaran Mandiri Di Masa New Normal. Pelita Masyarakat, 2(1), 64-71. https://doi.org/10.31289/pelitamasyarakat.v2i1.4222

Setiawan, A. (2012). Pencapaian prestasi olahraga melalui kegiatan ekstrakurikuler pencak silat. Jurnal Pelopor Pendidikan, 3(1), 71-80.

Waskita, R. A., Fiati, R., \& Murti, A. C. (2018). Animasi 3D Teknik-Teknik Pencak Silat Berbasis Android. Simetris: Jurnal Teknik Mesin, Elektro Dan Ilmu Komputer, 9(1), 121-128. https://doi.org/10.24176/simet.v9i1.1829

Yaumi, M. (2018). Media dan Teknologi Pembelajaran. In Jakarta.

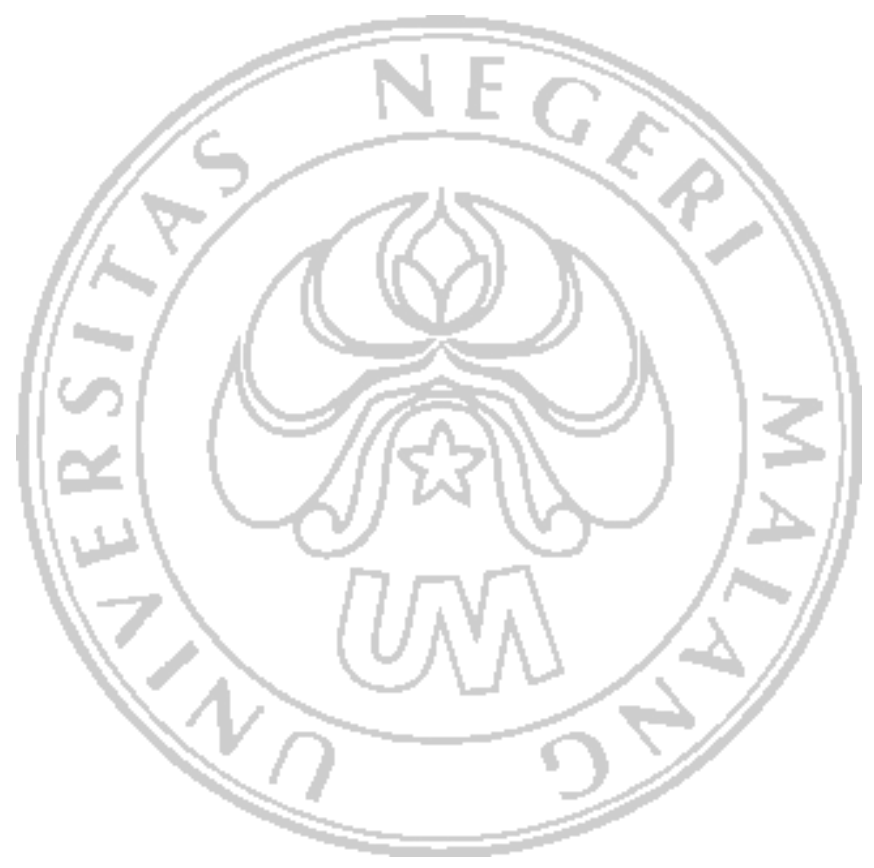

